\title{
An Overview of Self-esteem of Visually Blind People in One Social Rehabilitation Center, Bekasi Indonesia
}

\author{
Sellie Damayanti ${ }^{*}$, Maulina Handayani ${ }^{2}$ \\ \{damayantisellie@gmail.com ${ }^{1}$, maulina_h@uinjkt.ac.id ${ }^{2}$ \} \\ *corresponding author \\ Nursing Study Program, Faculty of Health Sciences \\ UIN Syarif Hidayatullah Jakarta, Ciputat, 15419. Indonesia ${ }^{1,2}$
}

\begin{abstract}
Physical limitations (disabilities), such as Visual impairment may affect selfesteem processing. The Nurse must be capable to patients with disabilities concerning variations in patient self-esteem. Therefore, this study aimeds to describe the self-esteem of blind people. This research used a descriptive cross-sectional design. The Sample was 42 respondents of Blind people at the Tan Miyat Bekasi Social Rehabilitation Center for People with Netra Sensory Disability (BRSPDSN) which was obtained from The total sampling method. Data collection used a validated Self-esteem scale, Rosenberg Selfesteem Scale (RSES) instrument. Data analysis used a univariate test to get a percentage and proportion values. The results showed that 25 respondents $(59,5 \%)$ had high selfesteem and 17 other respondents $(40,5 \%)$ had lower self-esteem. Some of the groups that had the lowest self-esteem include the early adolescence group (54.55\%), Early adulthood $(57,14 \%)$, late adulthood (100\%), and the SMPLB education group (66.67\%). The majority of the groups that had the highest self-esteem include the late adolescence group (71.3\%), and childhood (100\%). Based on gender male group (61.54\%) and female group (56.25\%). Based on the level of education, vocational education group $(65.22 \%)$, and SDLB education group (61.54\%). Based on the type of Visual impairment, low vision group $(63.64 \%)$ and total blindness group $(65.22 \%)$. Based on the history of Visual impairment, Visual impairment since birth as many as $(65.22 \%)$ and incidence $(52.63 \%)$. Based on the place of residence, respondents who lived in the dormitory were $(59.46 \%)$ and at home (60\%). Respondents with 1 activity have equalization in each category of self-esteem and respondents with more than one activity $66.67 \%$ have high self-esteem and 33,33\% have low self-esteem . Research recommendations for nursing care that nurses can implement activities to increase self-actualization and explore the positive abilities of patients, especially people with disabilities.
\end{abstract}

Keywords: Blind People, Self-Esteem nursing care

\section{Introduction}

People with disabilities are individuals who have physical, intellectual, mental, and/or sensory limitations for a relatively long period who have obstacles in interacting with the surrounding environment effectively and fully [1]. Among people with disabilities are blind people who have both partial vision impairment (cannot read 12-point text in normal light even with glasses; low vision) or totally (total blindness) [2]. 
In 2010 , globally, $4.24 \%$ of the population experienced visual impairment with $0.58 \%$ being blind and $3.65 \%$ suffering from low vision [3]. In Indonesia, $1.5 \%$ of the population experienced visual impairment in 1993 and it increased to $1.67 \%$ in 2007 which made Indonesia the second highest prevalence of Visual impairment in the world. The Visual impairment rate above $1 \%$ makes Visual impairment in Indonesia not only a health problem but also a social problem [4]. In 2014, the proportion of Visually blind people in Indonesia was the secondlargest proportion of all people with disabilities, namely 29.6\% [5]. In 2014, West Java was the third-highest province for blind people, namely 2.2\%.5 3582 blind people in Bekasi with the largest proportion in East Bekasi (14.3\%) [6].

Human nature in life certainly has needs that must be met. One of them needs to be respected. In Maslow's hierarchical theory, the individual's need for self-esteem is the 4th important need as a need at a perfect level before self-actualization [7]. Visual impairments affect the information obtained, perceptions, and experiences that have an impact on a person in determining their self-esteem [8],[9],[10]. Previous studies have shown that $40 \%$ of people with disabilities have low self-esteem. Also, disability also affects the perception of social support [11].

A preliminary study conducted by researchers through interviews with 2 Visually blind people at the Social Rehabilitation Center Tan Miyat Bekasi. The results of the preliminary study showed that 1 person who was blind since birth said that he felt normal when he could not see this world, now he has accepted his situation, but he considers himself bad, has no advantages, there is nothing to be proud of about him and have no ideals. Another blind person who experienced Visual impairment (Low Vision) when he was 5 years old, he said he was sad when his eyesight decreased, then he felt ashamed because many people excluded him, he felt that he was different from other friends and chose to reduce interactions. When she first entered the orphanage, she also felt ashamed and scared, afraid that her friends were ignorant. She does not know what positive strengths or abilities; she has but she has accepted her current condition and has professional aspirations in the field of beauty. The results of the observations also show that there is a solitary behavior of the group when they are on the move.

The effect of low self-esteem is a feeling of being empty and separated from others, and sometimes causes depression, anxiety, or prolonged feelings of anxiety [12]. Low self- esteem also results in depression, suicide, anorexia nervosa, juvenile delinquency, and other adjustment problems [13]. The impact of high self-esteem is to help increase initiative, resilience and feelings of self-satisfaction [14].

Allah SWT said in Surah Al-Imran verse 139 "Do not (feel) weak, and do not (also) be sad, because you are the highest degree if you are believers." Humans do not need to be sad and feel inferior because what is assessed by Allah SWT is the level of taqwa [15].

This research was conducted based on the number of blind people in Bekasi who needed attention and research in West Java, especially Bekasi, had never been carried out. The choice of the Social Rehabilitation Center for Persons with Sensory Blind Disabilities (BRSPDSN) Tan Miyat Bekasi was also because Tan Miyat Bekasi was a rehabilitation institution for blind people in Bekasi. Researchers aim to identify an overview of the self- esteem of blind people at the Social Rehabilitation Center.

\section{Method}

This study used a descriptive observational study with cross-sectional study design. The research population for blind people at the Social Rehabilitation Center for Persons with Sensory Blind Disabilities (BRSPDSN) at Miyat Bekasi in February-April 2019 corresponded to 45 people. Sampling used a total sampling technique to the study population that met the inclusion criteria. The incusion criteria consist a beneficiary in BRSPDSN, not having multiple disabilities, and willing to be respondents. Based on the inclusion criteria, a sample size of 42 respondents was obtained.

The instruments used in data collection consisted of respondents' demographic questionnaire and self-esteem questionnaire. The data were collected using a self-esteem questionnaire instrument developed by Rosenberg (1965) which was translated in to Indonesian by Azwar. This research was not conducted to re-test validity and reliability. The Indonesian version of the Rosenberg Self-Esteem Scale has been tested for validity using the item-total correlation. Azwar reported that the item-total correlation coefficient was between 0.415-0.703 for ten items in a scale with a total number of respondents of 71. Martanih et al (1991) found the alpha coefficient for this scale to be $0.439(\mathrm{n}=300)$. The reliability test result was 0.8587 . 
Therefore, it is reliable. ${ }^{17}$ The questionnaire consisted of 10 questions about self- acceptance, social feelings with others, believers achieved, and role fulfillment. Questionnaire had 5 favorable questions at numbers $1,2,4,6,7$ and 5 unfavorable questions at numbers $3,5,8,9,10$. The questionnaire was printed in braille without changing the language or items on the original questionnaire. The form of a braille questionnaire was used to make it easier for blind people to understand it and maintain privacy in assessing self-esteem in themselves. The data were analyzed to obtain a distribution, proportion, and proportion values. According to Azwar (2012), The results of the assessment from the questionnaire are categorized into two, namely low selfesteem and high self-esteem. The categorization used is cut-off point data with a score of $<20$ is said to be low self-esteem and the total score $\geq 20$ including high self-esteem.16 Researchers determine the cut-of point return value because of the specific and different characteristics of the sample. Categorization is based on the distribution of data distribution. The parameter used to see the distribution of data using Shapiro Wilk because the sample is less than 50 respondents. The data on the value of the self- esteem variable is not normally distributed with a p-value of 0.004 ( $p<0.05$ ), therefore the cut of point uses the median value. The level of self-esteem is determined by the total score obtained from the sum of the answers. The highest score is 40 and the lowest score is 0 . This data is not normally distributed, so the cut of point uses the median. The scores are then grouped into two categories, namely high self-esteem with a total score of $\geq 25.00$ and low self-esteem with a total score of $<25.00$.

\section{Result}

Table 1. Distribution Proportion of respondent characteristics

\begin{tabular}{|c|c|c|c|}
\hline \multirow[b]{2}{*}{ No. } & \multicolumn{3}{|c|}{ Distribution Proportion of respondent characteristics } \\
\hline & Characteristics of the respondent & Frequency $(n)$ & Percentage (\%) \\
\hline \multirow{6}{*}{1} & Age & & \\
\hline & a. Childhood (5-11 years) & 2 & 4,8 \\
\hline & b. Early adolescence (12-16years) & 11 & 26,2 \\
\hline & c. Late adolescence (17-25years) & 21 & 50 \\
\hline & d. Early adulthood (26-35 years) & 7 & 16,7 \\
\hline & e. Advanced adulthood (36-45 years) & 1 & 2,4 \\
\hline \multirow{3}{*}{2} & Gender & & \\
\hline & a. Female & 16 & 38.1 \\
\hline & b. Male & 26 & 61.9 \\
\hline \multirow{4}{*}{3} & Education & & \\
\hline & a. SDLB & 13 & 31 \\
\hline & b. SMPLB & 6 & 14,3 \\
\hline & c. Vocation & 23 & 54,8 \\
\hline \multirow{4}{*}{4} & Types of Visual impairment & & \\
\hline & a. TotalBlind & 20 & 47,6 \\
\hline & b. Low-vision & 22 & 52,4 \\
\hline & History of Visual impairment occurs & & \\
\hline \multirow[t]{2}{*}{5} & a. From birth & 23 & 54,8 \\
\hline & b. Accident & 19 & 45,2 \\
\hline \multirow{3}{*}{6} & Residence & & \\
\hline & a. Home & 5 & 11,9 \\
\hline & b. Dormitory & 37 & 88,1 \\
\hline \multirow{3}{*}{7} & Activity & & \\
\hline & a. 1 Activity & 18 & 42,9 \\
\hline & b. >1Activity & 24 & 57,1 \\
\hline \multirow{3}{*}{8} & Self-Esteem & & \\
\hline & a. Low & 17 & 40,5 \\
\hline & b. High & 25 & 59,5 \\
\hline
\end{tabular}

Table 1 shows that the majority of respondents are late adolescents $(50.0 \%) .4 .8 \%$ of the respondents are childhood and $2.4 \%$ are late adulthood. $61.9 \%$ of the respondents are male. $54.8 \%$ of respondents took education up to vocational level, $31 \%$ through special primary school, and $14.3 \%$ through special junior high school education. $52.4 \%$ of respondents have low vision, blindness, and $47.6 \%$ have total blindness. $54.8 \%$ of respondents experienced blindness from birth and $45.2 \%$ of respondents experienced blindness due to incidents. The majority of respondents live in dormitories (88.1\%). 57.1\% of respondents were involved in more than 1 activity a day and $42.9 \%$ of respondents only had one activity per day. The majority of respondents had high self-esteem, namely $59.5 \%$ and only $40.5 \%$ of respondents had low self-esteem. 
Table 2. Cross-analysis of Respondent Characteristics with Self-Esteem

\begin{tabular}{|c|c|c|c|c|c|}
\hline \multirow{2}{*}{\multicolumn{2}{|c|}{ Characteristics of the respondent }} & \multicolumn{4}{|c|}{ Self-esteem } \\
\hline & & \multicolumn{2}{|c|}{ Low } & \multicolumn{2}{|c|}{ High } \\
\hline & & $\mathbf{n}$ & $\%$ & $\mathbf{n}$ & $\%$ \\
\hline \multirow[t]{5}{*}{ Age } & Childhood (5-11 years) & 0 & 0,00 & 2 & 100,00 \\
\hline & Early adolescence (12-16 years) & 6 & 54,55 & 5 & 45,45 \\
\hline & Late adolescence (17-25 years) & 6 & 28,57 & 15 & 71,43 \\
\hline & Early adulthood (26-35 years) & 4 & 57,14 & 3 & 42,86 \\
\hline & Advanced adulthood ( $36-45$ years) & 1 & 100,00 & 0 & 0,00 \\
\hline \multirow[t]{2}{*}{ Gender } & Female & 7 & 43,75 & 9 & 56,25 \\
\hline & Male & 1 & 38,46 & 16 & 61,54 \\
\hline \multirow[t]{3}{*}{ Education } & SDLB & 5 & 38,46 & 8 & 61,54 \\
\hline & SMPLB & 4 & 66,67 & 2 & 33,33 \\
\hline & Vocational & 8 & 34,78 & 15 & 65,22 \\
\hline \multirow[t]{2}{*}{ Type of Visual impairment } & Total blind & 9 & 45,00 & 11 & 55,00 \\
\hline & Low vision & 8 & 36,36 & 14 & 63,64 \\
\hline \multirow{2}{*}{$\begin{array}{l}\text { History of Visual } \\
\text { impairment occurs }\end{array}$} & From birth & 8 & 34,78 & 15 & 65,22 \\
\hline & Accident & 9 & 47,37 & 10 & 52,63 \\
\hline \multirow[t]{2}{*}{ Residence } & Home & 2 & 40,00 & 3 & 60,00 \\
\hline & Dormitory & 15 & 40,54 & 22 & 59,46 \\
\hline \multirow[t]{2}{*}{ Activity } & 1 Activity & 9 & 50,00 & 9 & 50,00 \\
\hline & $>$ 1Activity & 8 & 33,33 & 16 & 66,67 \\
\hline
\end{tabular}

Table 2 shows the cross-tabulation between self-esteem and respondent characteristics. Based on the age category, the highest percentage of respondents who have high self- esteem is in childhood as much as $100 \%$ of the total respondents which corresponded to 2 people. In early adolescence (12-16 years) as much as $45.45 \%$ ) have high self-esteem and $54.55 \%$ have low self-esteem. In the late teens (17-25 years) $71.3 \%$ have high self-esteem, and $28.57 \%$ have low self-esteem. In early adulthood (26-35 years) who have high self- esteem is $42.85 \%$ and $57.14 \%$ low self-esteem, and in late adulthood (36-45 years) 100\% have low self-esteem. The results of self-esteem based on gender showed $56.25 \%$ of women had high self-esteem and $43.75 \%$ had low self-esteem, while $61.54 \%$ of men had high self-esteem and $38.46 \%$ had low self-esteem. At the vocational level, those with high self-esteem $65.22 \%$ and $34.78 \%$ have low self-esteem, at SDLB $61.54 \%$ have high self- esteem and $38.46 \%$ have low selfesteem and in special education, $33.33 \%$ have high self- esteem while $66.67 \%$ have low selfesteem. In low vision, $63.64 \%$ have high self-esteem and $36.36 \%$ have low self-esteem, while in total blindness 55\% have high self-esteem and $45 \%$ have low self-esteem. Respondents with a history of blindness since birth $65.22 \%$ have high self-esteem and $34.78 \%$ have low self- esteem, while those with a history of blindness due to incidence $52.63 \%$ have high selfesteem and $47.37 \%$ have low self- esteem. $60 \%$ of respondents who live in homes have high self- esteem and $40 \%$ have low self-esteem, while $59.46 \%$ of respondents who live in dormitories have high self-esteem and $40.54 \%$ have low self-esteem. $66.67 \%$ of respondents who have more than 1 activity have high self-esteem and 33,33\% have low self-esteem while respondents who have 1 distributed activity equally in each category.

\section{Discussion}

A person's self-esteem is shaped according to the acceptance and attention he feels. Over time, a person will get to know himself and his environment more and more so that self- esteem tends to decline in adolescence and fluctuates in adulthood and old age depending on the environment and the attitudes he has [9]. It was shown from the results of the study that high self-esteem was in childhood and in Advanced adulthood.

The male has higher self-esteem than female. Men, in general, have higher self-esteem compared to women who tend to be more sensitive in perceiving/assessing the environment and having low adjustment to a healthy environment [1]. Self-esteem associated with the level of education is also described in this study. The majority of respondents with SDLB and Vocational education have high self-esteem. Meanwhile, respondents with a SMPLB education level have low self-esteem. This is relevant to previous research where the lower the level of education the lower the self-esteem and pride and trust they have [14].

In the history of visual impairment, high self-esteem was more in Visual impairment since birth. Total blindness means that the person has completely lost the function of sight even though vision is one of the tools of life informing experiences that stimulate awareness of selfquality to shape one's self-esteem [9]. This finding is relevant to the acceptance that the person has. Visual impairment caused by incidents makes acceptance more difficult compared to get it since birth. This is also related to motivation and enthusiasm and adjustment to changes experienced in people with blindness due to incidents [17]. 
The results showed that high self-esteem is greater for respondents who live in the home environment. The home environment with good family support will greatly affect the perception and high self-esteem of the person. The school environment that affects the state of self-esteem depends on the interaction between friends and the role of teachers in carrying out education without discrimination and emphasizes the difference in the quality of life [16]. The role of the environment (family, community, school) can help eliminate potential problems that can hinder the psycho-social development of blind people due to their limited abilities [19]. The feeling of worth the individual has come from his daily environmental support. Social support is closely related to self-esteem, so the more positive the acceptance of social support, the higher the selfesteem of the blind [20].

Respondents who have more than 1 activity have higher self-esteem while respondents who have 1 equally distributed activity in each category. Previous research has shown that high self-esteem can be found in persons with disabilities who have regular training activities [17]. This is due to the perception that doing activities actively and regularly can form stronger physical strength and endurance so that it has an impact on self-pride. This increases the selfesteem that these trained disabled people have. Self-esteem is an important aspect in shaping a person's behavior because self-esteem is the main manifestation of the frame of mind, decisions taken, and individual goal values. The stronger the self-esteem, the higher the self- confidence one has, and vice versa [18]. In gaining life experiences, blind people use other senses that can still function properly. This is related to the perception of the environment that is accepted by the person including the family and social environment [19].

BRSPDSN Tan Miyat Bekasi has a service process with three stages, namely the social rehabilitation service phase with the initial approach phase, acceptance, the rehabilitation service phase in the form of physical therapy, mental therapy, religious spirituality, social therapy, and livelihood therapy, then the resocialization stage and the advanced coaching stage with social workers, psychologists, skills instructors, and nurses. This certainly can help blind people be able to carry out activities like normal people supported by an inclusive environment. Activities carried out at Tan Miyat Bekasi include physical guidance, mental guidance, social guidance, ADL and OM guidance, skills guidance (sports massage, Shiatsu, reflection, cosmetic massage, computer braille, and plaiting), in addition to guidance there are Case Conference activities carried out once every two months and Resocialization which is divided into two stages, firstly Work-Learning Practices for 30 working days at institutions outside the Ministry of Social Affairs and then distribution that is preceded by entrepreneurial activities before the blind enter the community.

The limitation of this study is that the sample used in the study is small, so it cannot describe the blind self-esteem widely. The number of research samples did not include all members of BRSPDSN Tan Miyat Bekasi who had been actively registered in the Balai because several members had been transferred to the company and some did not fit the researchers' inclusion criteria. Further researchers can examine the factors that influence the self-esteem of blind people or research with the in-depth interview method to better understand the meaning of self-esteem in blind people who already have high self-esteem.

\section{Conclusion}

Some groups that mostly have low self-esteem include early adolescence, late adulthood, and groups with special high school education (SMPLB) (66.67\%). And Ssome groups thats that have the highest self-esteem include the late adolescence group $(71.3 \%)$, and childhood $(100 \%)$, male group $(61.54 \%)$ and female group $(56.25 \%)$, vocational education group $(65.22 \%)$, and SDLB education group (61.54\%), low vision group (63.64\%) and total blindness group (65.22\%), Visual impairment since birth (65.22\%) and incidence (52.63\%), lived in the dormitory were $(59.46 \%)$ and at home $(60 \%)$. Respondents with 1 activity have equalization in each category of self-esteem and respondents with more than one activity $66.67 \%$ have high self-esteem and 33,33\% have low self-esteem.

Balai Tan Miyat Bekasi can re-activate mental health guidance services for all beneficiaries (visually impaired). For nursing, the results of the level of vision of the blind can be used as learning materials, especially for mental nurses in providing mental nursing care about self-esteem in persons with disabilities and for further researchers can examine the factors that affect the self-esteem of the blind or research with in-depth interviews to better find out the meaning of self-esteem in blind people who already have high self-esteem.

Acknowledgments. The researcher would like to thank the management of the hall and all the special Friend soft he blind BRSPDSN Tan Miyat Bekasi.

\section{References}

[1] UU Republik Indonesia Nomor 8. Concerning disability management. Retrieved from http://pugpupr.pu.go.id/_uploads/PP/UU.No.8Th.2016.pdf. (2016) 
[3] WHO. Global Data on Visual Impairment and Blindness. Retrieved from http://www.who.int/blindness/data_maps/VIFACTSHEETGLODAT2010full. pdf.accessed 30 January 2019. (2012).

[4] KEMENKES. Situasi Penyandang Disabilitas. Jakarta: Pusat Data dan Informasi Kementerian Kesehatan RI. (2014).

[5] KEMENKES RI. Situasi Gangguan Penglihatan dan Kebutaan. Retrieved from Infodatinpenglihatan.pdf (2014).

[6] BPS. Population According to Age Group and Level of Difficulty in Viewing Bekasi City. Retrieved from www.bps.go.id.(2010)

[7] Maslow, Abraham. Motivation and Personality. Jakarta: Rajawali.(2010)

[8] Atmaja, Rinarki. Education and Guidance for Children with Special Needs. Bandung: PT Remaja Rosdakarya.(2018)

[9] Efendi, M. Pengantar Psikopedagogik Anak Berkelainan. Jakarta : Bumi Aksara. (2009).

[10] Potter \& Perry. Nursing Fundamentals. Jakarta: Salemba Medika.(2010)

[11] Irawati, R. I. Gambaran Harga Diri Siswa Tunanatera di Sekolah Luar Biasa (SLB-A) TPA Bintoro Kabupaten Jember. e-Jurnal Pustaka Kesehatan, Universitas Jember.(2016)

[12] Widyasri, I. S. Hubungan antara Persepsi terhadap Dukungan Sosial dengan Harga Diri pada Tunanetra. Jurnal Psikologi Ukrida, 1. (2013).

[13] Santrock, J. W. Life Span Development. Jakarta: Erlangga. (2012)

[14] Gozuyilmaz, A., Baran, G. A studi on self-esteem in married adolescent according to pregnancy an education level. Social and Behavioral Science;9 1342-1346. Retrieved from http;//ac.elscdn.com. (2010).

[15] Departemen Agama RI. Al-Qur'an dan Terjemahannya. Surakarta : Media Insani. Departemen. (2007).

[16] Azwar, S. Penyusunan Skala Psikologi. Edisi-2. Yogyakarta : Pustaka Pelajar. (2012)

[17] Azwar, S. Reabilitas dan Validitas, edisi-4. Yogyakarta: Pustaka Pelajar Azwar. (2012)

[18] Intan, dkk. Resiliensi Mahasiswa Tunanetra (Studi Kasus Terhadap Mahasiwa Tunanetra Tidak dari Lahir fi Fakultas Ilmu Pendidikan Universitas Negeri Yogyakarta). Yogyakarta: UNY. (2017).

[19] Ermanza, G.H. Hubungan Citra Tubuh dengan dengan Harga Diri Remaja Putri yang Obesitas. Skripsi, Universitas Indonesia, Depok, Indonesia. (2008).

[20] Shinta Desrina \& Dewi Sartika. Hubungan Social Support dengan Self Esteem pada Tunanetra Buta di Panti Sosial Wyata Guna. Jurnal Psikologi Volume 2, No.2, Tahun 2016 Prosiding Psikologi ISSN: 2460-6448. (2016). 